\title{
2,3,7,8-Tetrachlorodibenzo-p-dioxin suppress AChE activity in NGF treated PC12 cells
}

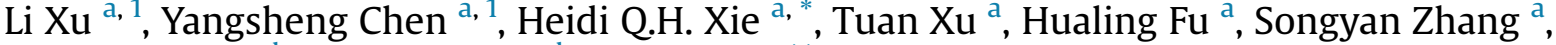 \\ Karl W.K. Tsim ${ }^{\mathrm{b}}$, Cathy W.C. Bi ${ }^{\mathrm{b}}$, Bin Zhao ${ }^{\mathrm{a},{ }^{* *}}$ \\ a State Key Laboratory of Environmental Chemistry and Ecotoxicology, Research Center for Eco-Environmental Sciences, Chinese Academy of Sciences, \\ University of Chinese Academy of Sciences, Beijing 100085, China \\ ${ }^{\mathrm{b}}$ Division of Life Science, The Hong Kong University of Science and Technology, Clear Water Bay Road, Hong Kong, China
}

\section{A R T I C L E I N F O}

\section{Article history:}

Received 8 January 2016

Received in revised form

7 July 2016

Accepted 4 August 2016

Available online 5 August 2016

\section{Keywords:}

AChE

Acetylcholinesterase

Dioxin

2,3,7,8-TCDD

PC12

Neuronal differentiation

NGF

Nerve growth factor

\begin{abstract}
A B S T R A C T
PC12 is a well studied cell model for neuronal differentiation. AChE is also considered as a marker for neuronal differentiation. In this study, we detected the change of AChE activity during the NGF induced differentiation of PC 12 cells, and targeted on the ratio of the activity of AChE on the cell surface, and found that NGF mainly increased the intracellular AChE activity. Dioxin is a kind of persistent organic pollutants which have extreme impact on human health and widely distributed all over the world. Recently, AChE was reported as a target of the toxicity of dioxin. Here we investigated the effect of 2,3,7,8-tetrachlorodibenzo-p-dioxin (TCDD) on AChE activity in the PC12 cells, and found that at the later stage of differentiation, TCDD could decrease the AChE activity. This down regulation might not related to transcriptional regulation.
\end{abstract}

๑) 2016 Elsevier Ireland Ltd. All rights reserved.

\section{Introduction}

Dioxin refers to a group of high persistent organic environmental contaminants with similar chemical structures, including polychlorinated dibenzo-p-dioxins (PCDDs), polychlorinated dibenzofurans (PCDFs), and polychlorinated biphenyls (PCBs) [1]. Hundreds of congeners of dioxins are generated during synthetic processes including waste incineration, metal smelting. Since these environmental contaminants are highly resistant to metabolism in vertebrate species, biomagnification occurs through the food chain, and high tissue concentrations occur in top predator species, including humans [2]. In the family of dioxin, the halogenated aromatic hydrocarbon 2,3,7,8-tetrachlorodibenzo-p-dioxin $(2,3,7,8$ TCDD, dioxin) is the most intensively studied one, and reported to be exerting various kinds of impacts on human health.

\footnotetext{
* Corresponding author.

** Corresponding author.

E-mail addresses: qhxie@rcees.ac.cn (H.Q.H. Xie), binzhao@rcees.ac.cn (B. Zhao).

$1 \mathrm{Xu}$ and Chen contributed equally to this work.
}

Epidemiology and related studies show that exposure to TCDD results in multiple toxic effects, including immunotoxicity, neurotoxicity, carcinogenesis, endocrine toxicity, productive toxicity etc [3-5].

Acetylcholinesterase (AChE) activity and expression level can be down regulated by TCDD in neuronal cells $[3,6]$. Thus AChE could be considered as a target of the neuronal toxicity of dioxin. AChE has several types of transcripts by alternative splicing in the $3^{\prime}$ region of primary transcripts $[7,8]$. The "tailed" isoform of $\mathrm{AChE}\left(\mathrm{AChE}_{\mathrm{T}}\right)$ is one of the transcripts that exists in all vertebrates, and can form tetrameters associated with a proline-rich membrane anchor (PRiMA) as globular form AChE (G4 AChE) in the brain and muscle [9-11].

The expression level and enzymetic activity of AChE would be increased during neuronal differentiation. Cultured pheochromocytoma PC12 cell line is commonly being used for the detection of neuronal differentiation in responding to various stimuli, e.g. nerve growth factor (NGF) [12,13]. In this study, we used PC12 cells as the study model, investigated the change of AChE activities upon the treatment of NGF and the effect of TCDD on AChE during different stages of NGF induced PC12 differentiation. 


\section{Materials and methods}

\subsection{Materials}

2,3,7,8-TCDD was purchased from Wellington Laboratories Inc (Ontario, Canada), and dissolved in dimethyl sulfoxide (DMSO).

\subsection{Cell culture and drug treatment}

Pheochromocytoma PC12 cells, a cell line derived from rat adrenal medulla, were obtained from American Type Culture Collection (ATCC, Manassas, VA), and which were maintained in Dulbecco's modified Eagle's medium supplemented with 6\% fetal calf serum, $6 \%$ horse serum, 100 units $/ \mathrm{mL}$ penicillin, and $100 \mu \mathrm{g} / \mathrm{mL}$ streptomycin in a humidified $\mathrm{CO}_{2}$ (7.5\%) incubator at $37{ }^{\circ} \mathrm{C}$. Fresh medium was supplied every other day. All culture reagents were purchased from Life Technologies (Carlsbad, CA). During the treatment with NGF and TCDD, cultured PC12 cells were serum starved for $3 \mathrm{~h}$ in Dulbecco's modified Eagle's medium supplemented with $1 \%$ fetal calf serum, $1 \%$ horse serum and penicillinstreptomycin, and then which were treated with the drug for 12 , 24,48 and $72 \mathrm{~h}$.

\subsection{RNA extraction, reverse transcription and real-time $P C R$}

To quantify the mRNA expression levels of the synaptic proteins, total RNA from cultured rat cortical neurons were isolated by GeneJET RNA Purification Kit (Thermo Scientific, Waltham, MA) according to the manufacture's instruction. $3 \mu \mathrm{g}$ of total RNA was reverse-transcribed by RevertAid First Strand cDNA Synthesis Kit (Thermo Scientific) according to the manufacture's instruction, and obtained the cDNA of each sample.

Real-time quantitative PCR was performed on equal amounts of cDNA by using GoTaq Qpcr Master Mix (Promega, Madison, WI) according to the manufacturer's instructions. The SYBR green signal was detected by Roche 480 Real-Time PCR System. PCR products were analyzed by gel electrophoresis, and the specificity of amplification was confirmed by the melting curves. The primers were as follows: Total AChE: 5'-CGCAGCAATACGTGAGCCTGAA-3' (S) and 5'-TGTGGCGCTG AGCAATTTGGG-3' (AS) for rat (110bp; BC094521.1). AChET: 5'-CTCCCCAAATTG CTCAGCG-3' (S) and 5'TCACAGGTCTGAGCAGCG-3' (AS) (147bp; [14]). GAPDH: 5'-AGTTCAACGGCACAGTCAAG-3' (S) and 5'-TACTCAGCACCAGCATCACC- $3^{\prime}$ (AS) (118bp; NM_017008.4).

\subsection{Determination of AChE activity}

AChE activities were determined by Ellman assay [9,15].

After treatments, cultured PC12 cells were collected in PBS (3 wells of cells from 6-well-plate were combined in one tube) and washed for 3 times and then resuspended in $1 \mathrm{~mL}$ of low salt lysis buffer ( $\mathrm{pH}=7.5$ ) without Triton $\mathrm{X}-100$ and all of the samples were diluted to equal cell density. Each sample was then equally divided into 3 parts: (1) anchored on the cell surface (cells were suspended in low salt lysis buffer without Triton X-100, AChE activity of the cell suspension was determined), (2) the background reading (cells were centrifuged and AChE activity in the supernatant was determined) (3) the total AChE activity from both intracellular and surface (Triton X-100 was added to the final concentration of $0.5 \%$, AChE activity of total cell lysate was determined). Readings of sample (1) and (3) minus readings of sample (2) obtained the absolute AChE activity on the cell surface and from total cell, respectively.

\subsection{Statistical analysis and other assays}

Statistical analyses were performed using two way ANOVA. Statistically significant changes were classed as [ $\left.{ }^{*}\right]$ where $\mathrm{p}<0.001$.

\section{Results and discussion}

\subsection{Cell viability}

The treatment of NGF and TCDD at the concentration of $1 \times 10^{-11}$ to $1 \times 10^{-9}$ did not affect the viability of PC12 cells (Supplementary Fig. 1).

\subsection{NGF increases AChE activity}

NGF was applied to the cultured PC12 cells at the concentrations of $15 \mathrm{ng} / \mathrm{mL}$ and $50 \mathrm{ng} / \mathrm{mL}$. Samples were harvested after the

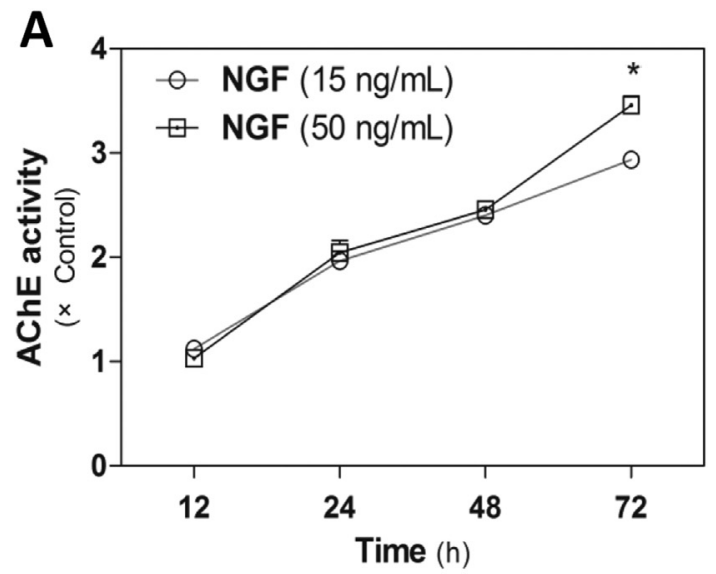

B

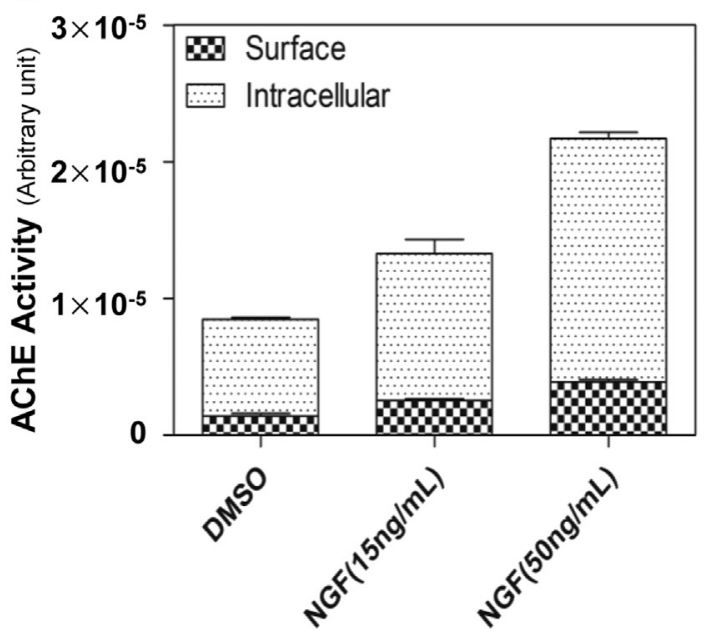

Fig. 1. AChE activity of NGF induced differentiated PC12 cells. (A): NGF increases total AChE activity in PC12 cells. PC12 cells were harvested at the different times points $(12,24,48$ and $72 \mathrm{~h}$ ) under the treatment of NGF at the concentration of 15 and $50 \mathrm{ng} / \mathrm{mL}$. Total protein was extracted from each sample to perform the Ellman assay, and results were normalized by the protein concentrations. Values are expressed as the fold of change (X Basal) against the control (the AChE activity of PC12 cells treated by DMSO for $12 \mathrm{~h}$; set as 1 ), and in Mean \pm SEM, $\mathrm{n}=3$, each with triplicate samples. *where $\mathrm{p}<0.01$ compared to the value of NGF $15 \mathrm{ng} / \mathrm{mL}$ for $72 \mathrm{~h}$. (B): Ratio of AChE activity on cell surface in NGF induced differentiated PC 12 cells. PC12 cells were treated with NGF at the concentration of 15 and $50 \mathrm{ng} / \mathrm{mL}$ for $72 \mathrm{~h}$. AChE activity on cell surface and total AChE activity was determined respectively. Values are expressed as the arbitrary unit, and in Mean \pm SEM, $n=3$, each with triplicate samples 
treatment for $12,24,48$ and $72 \mathrm{~h}$, respectively. Cell differentiation was induced by NGF, and the morphological change can be obviously observed (Supplementary Fig. 2). The enzymatic activity of AChE was measured by Ellman assay. As shown in Fig. 1A, AChE activity could be increased by NGF in time-dependent manners. During the treatment for $48 \mathrm{~h}, \mathrm{NGF}$ at 15 and $50 \mathrm{ng} / \mathrm{mL}$ showed no difference in enhancing the activity of AChE. After being treated for $72 \mathrm{~h}, \mathrm{NGF}$ at $50 \mathrm{ng} / \mathrm{mL}$ showed significantly higher effect compared with NGF at $15 \mathrm{ng} / \mathrm{mL}$. This result implies that AChE activity could be increased during NGF induced neuronal differentiation, and dose dependent manner could be observed at later stage of differentiation in cultured PC12 cells.

\subsection{The activity of AChE on the surface and in the cytosome under the treatment of NGF}

After treatment of NGF at different concentrations for $72 \mathrm{~h}$, the total AChE activity and activity of AChE on the cell surface were determined. Results show that NGF could increase activity of AChE

\section{A}

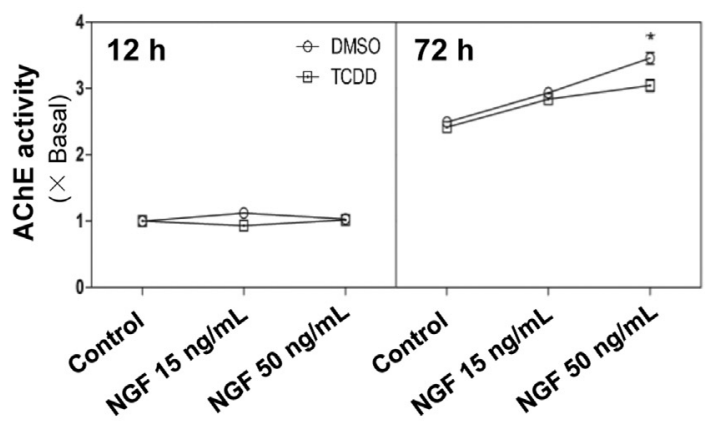

B
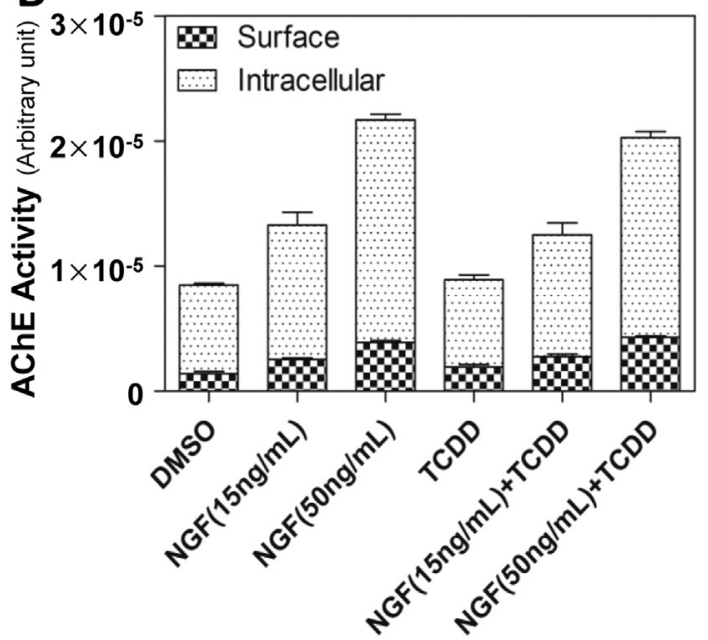

Fig. 2. TCDD affects the AChE activity of NGF induced differentiated PC 12 cells. (A): TCDD affects total AChE activity of NGF induced differentiated PC12 cells. PC12 cells were treated with TCDD with NGF, and equal volume of DMSO and NGF for $12 \mathrm{~h}$ (left panel) and $72 \mathrm{~h}$ (right panel). Total protein was extracted from each sample to perform the Ellman assay, and results were normalized by the protein concentrations. Values are expressed as the fold of change (X Basal) against the control (the AChE activity of PC12 cells treated by DMSO for $12 \mathrm{~h}$; set as 1 ), and in Mean \pm SEM, $\mathrm{n}=3$, each with triplicate samples. *where $\mathrm{p}<0.01$ compared to the value of NGF $50 \mathrm{ng} / \mathrm{mL}$ treatment without TCDD. (B): TCDD affects the ratio of AChE activity on cell surface in NGF induced differentiated PC 12 cells. PC12 cells were treated with TCDD with NGF, and equal volume of DMSO and NGF for $72 \mathrm{~h}$. AChE activity on cell surface and total AchE activity was determined respectively. Values are expressed as the arbitrary unit, and in Mean \pm SEM, $n=3$, each with triplicate samples. both intracellular and on the cell surface (Fig. 1B). Choi et al. reported that both PRiMA-linked G4 AChE and G1 AChE could be up regulated upon the treatment of dibutyrylcAMP $\left(\mathrm{Bt}_{2}\right.$-cAMP) and forskolin in cultured PC12 cells. Based on this result, they declared that stimulation of cAMP-dependent signaling pathway triggered the transcription of $\mathrm{AChE}_{\mathrm{T}}$ and PRiMA I genes, and increase the assembly of PRiMA-linked G4 AChE in PC12 cells [14]. NGF, as an endogenous neurotrophic factor, could activate a lot of signaling pathways mainly including mitogen-activated protein (MAP) kinase pathway, phosphatidylinositol 3-kinase signaling- Akt pathway, cAMP-dependent signaling pathway NF-kappa B dependent pathway, and regulates a variety of cellular activities [16-19]. In PC12 cells, cAMP-dependent signaling pathway is one of the pathways that activated by NGF, but not the dominant one. Thus, in our study, AChE activity on the cell surface did not increase upon the treatment of NGF, even though NGF could up regulate the total AChE activity. That means the assembly of PRiMA-linked G4 AChE in PC12 cells cannot be promisingly enhanced by NGF.

\subsection{TCDD affects AChE activity}

TCDD at the concentration of $1 \times 10^{-9} \mathrm{M}$ was applied to the cultured PC12 cells to investigate its influence on AChE activity during NGF induced neuronal differentiation. Results show that at the earlier stage of differentiation (NGF treated for $12 \mathrm{~h}$ ), TCDD cannot affect AChE activity; however, at later stage of differentiation (NGF treated for $72 \mathrm{~h}$ ), TCDD could slightly decrease AChE activity (Fig. 2A). The ratio of surface AChE activity to total AChE activity was also detected. Result shows that TCDD slightly
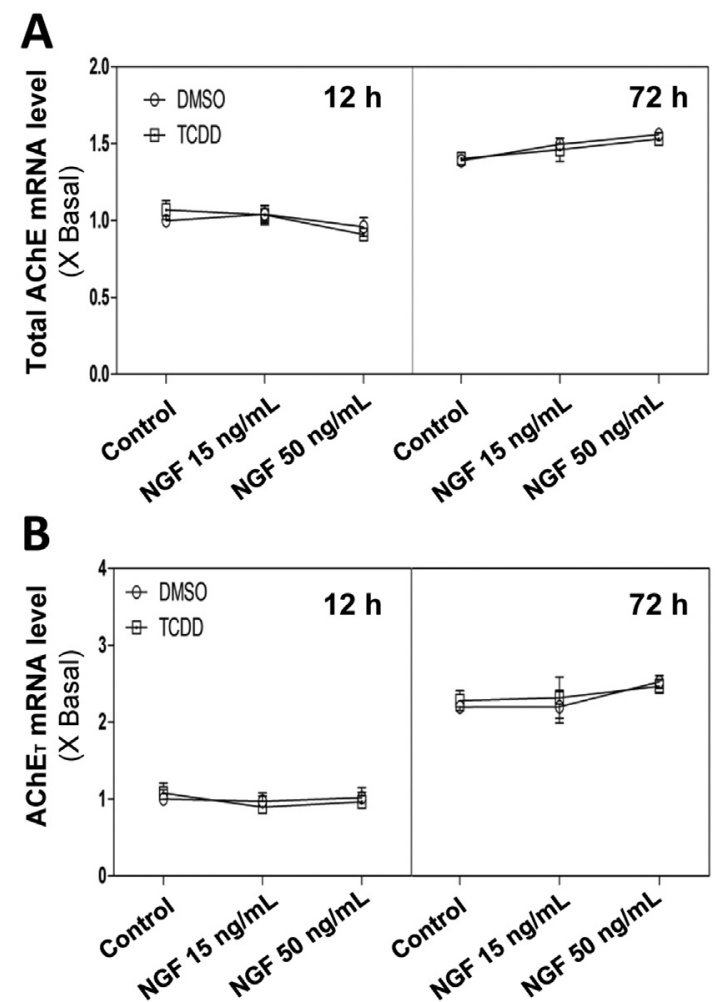

Fig. 3. TCDD does not change the mRNA level of AChE in NGF induced differentiated PC 12 cells. PC12 cells were treated with TCDD and NGF, and equal volume of DMSO and NGF for $12 \mathrm{~h}$ (left panel) and $72 \mathrm{~h}$ (right panel). Total RNA was extracted from the cell cultures. The mRNA level of total $A C h E(A)$ and $\mathrm{AChE}_{\mathrm{T}}(\mathbf{B})$ was analyzed by real-time quantitative PCR. Values are expressed as the fold of change (X Basal) against the control (AChE mRNA level of PC12 cells treated by DMSO for $12 \mathrm{~h}$; set as 1), and in Mean \pm SEM, $n=3$, each with triplicate samples. 
increased the percentage of cell surface AChE activity (Fig. 2B).

The TCDD concentration we used in this experiment is close to environmental levels. Previous work in our laboratory declared that dioxin could decrease AChE activity by about $15 \%$ in human-derived neuronal cells SK-N-SH [20]. In the present study, we found that total AChE activity of PC12 cells only could be decreased when the cells were differentiated and showed neuronal properties, while un-differentiated cells did not response to the treatment of TCDD.

\subsection{TCDD does not affect AChE mRNA level}

Total AChE mRNA level and $\mathrm{AChE}_{\mathrm{T}}$ mRNA level were determined by real-time PCR respectively upon the treatment of TCDD and NGF (Fig. 3A and B). Result shows that no significant differences could be observed between the TCDD group and DMSO group. This result implies that the influence of TCDD on AChE activity of differentiated PC12 cells is not a consequence of transcriptional regulation. Meanwhile, even though TCDD slightly increased the percentage of cell surface AChE activity, it did not obtain this effect by changing the mRNA expression level of $\mathrm{AChE}_{\mathrm{T}}$. The mechanism is being determined currently in our laboratory.

\section{Acknowledgement}

This research was supported by grants from Natural Science Foundation of China (21407171, 21377160, 21525730), the Strategic Priority Research Program of the Chinese Academy of Sciences (No. XDB14030400) and grant from Research Center for EcoEnvironmental Sciences (RCEES-QN-20130054F).

\section{Transparency document}

Transparency document related to this article can be found online at http://dx.doi.org/10.1016/j.cbi.2016.08.003.

\section{Appendix A. Supplementary data}

Supplementary data related to this article can be found at http:// dx.doi.org/10.1016/j.cbi.2016.08.003.

\section{References}

[1] P.K. Mandal, Dioxin: a review of its environmental effects and its aryl hydrocarbon receptor biology, J. Comp. Physiol. B 175 (2005) 221-230.

[2] M. Van den Berg, L.S. Birnbaum, M. Denison, M. De Vito, W. Farland, M. Feeley, H. Fiedler, H. Hakansson, A. Hanberg, L. Haws, M. Rose, S. Safe, D. Schrenk, C. Tohyama, A. Tritscher, J. Tuomisto, M. Tysklind, N. Walker, R.E. Peterson, The 2005 World Health Organization reevaluation of human and mammalian toxic equivalency factors for dioxins and dioxin-like compounds, Toxicol. Sci. 93 (2006) 223-241.

[3] H.Q.H. Xie, H.M. Xu, H.L. Fu, Q. Hu, W.J. Tian, X.H. Pei, B. Zhao, AhR-Mediated effects of dioxin on neuronal acetylcholinesterase expression in vitro, Environ. Health Perspect. 121 (2013) 613-618.
[4] M. Nishijo, J.I. Kuriwaki, E. Hori, K. Tawara, H. Nakagawa, H. Nishijo, Effects of maternal exposure to 2,3,7,8-tetrachlorodibenzo-p-dioxin on fetal brain growth and motor and behavioral development in offspring rats, Toxicol. Lett. 173 (2007) $41-47$

[5] J. Liu, C.M. Zhang, P.J. Coenraads, Z.Y. Ji, X. Chen, L. Dong, X.M. Ma, W. Han, N.J. Tang, Abnormal expression of MAPK, EGFR, CK17 and TGk in the skin lesions of chloracne patients exposed to dioxins, Toxicol. Lett. 201 (2011) 230-234.

[6] H.M. Xu, H.D.O.H. Xie, W.O. Tao, Z.G. Zhou, S.Z. Li, B. Zhao, Dioxin and dioxinlike compounds suppress acetylcholinesterase activity via transcriptional downregulations in vitro, J. Mol. Neurosci. 53 (2014) 417-423.

[7] J. Massoulie, S. Bon, N. Perrier, C. Falasca, The C-terminal peptides of acetylcholinesterase: cellular trafficking, oligomerization and functional anchoring, Chemico-biolog. Interact. 157 (2005) 3-14.

[8] K.W.K. Tsim, H.Q.H. Xie, A.K.L. Ring, N.L. Siow, K.K.Y. Ling, L.W. Kong, Transcriptional control of different acetylcholinesterase subunits in formation and maintenance of vertebrate neuromuscular junctions, J. Mol. Neurosci. 30 (2006) 189-192.

[9] C.W.C. Bi, W.K.W. Luk, M.L. Campanari, Y.H. Liu, L. Xu, K.M. Lau, M.L. Xu, R.C.Y. Choi, J. Saez-Valero, K.W.K. Tsim, Quantification of the transcripts encoding different forms of AChE in various cell types: real-time PCR coupled with standards in revealing the copy number, J. Mol. Neurosci. 53 (2014) $461-468$.

[10] V.P. Chen, R.C.Y. Choi, W.K.B. Chan, K.W. Leung, A.J.Y. Guo, G.K.L. Chan, W.K.W. Luk, K.W.K. Tsim, The Assembly of Proline-rich Membrane Anchor (PRiMA)-linked Acetylcholinesterase Enzyme glycosylation is required for enzymatic activity but not for oligomerization, J. Biol. Chem. 286 (2011) 32948-32961.

[11] H.Q. Xie, R.C.Y. Choi, K.W. Leung, N.L. Siow, L.W. Kong, F.T.C. Lau, H.B. Peng, K.W.K. Tsim, Regulation of a transcript encoding the proline-rich membrane anchor of globular muscle acetylcholinesterase - the suppressive roles of myogenesis and innervating nerves, J. Biol. Chem. 282 (2007) 11765-11775.

[12] D.K. Fujii, S.L. Massoglia, N. Savion, D. Gospodarowicz, Neurite outgrowth and protein synthesis by PC12 cells as a function of substratum and nerve growth factor, J. Neurosci. 2 (1982) 1157-1175.

[13] J. Schimmelpfeng, K.F. Weibezahn, H. Dertinger, Quantification of NGFdependent neuronal differentiation of $\mathrm{PC}-12$ cells by means of neurofilament-L mRNA expression and neuronal outgrowth, J. Neurosci. Methods 139 (2004) 299-306.

[14] R.C.Y. Choi, M.K.W. Mok, A.W.H. Cheung, N.L. Siow, H.Q. Xie, K.W.K. Tsim, Regulation of PRiMA-linked G(4) AChE by a cAMP-dependent signaling pathway in cultured rat pheochromocyoma PC12 cells, Chemico-Biological Interact. 175 (2008) 76-78.

[15] G.L. Ellman, K.D. Courtney, V. Andres, R.M. Featherstone, A. New, Rapid Colorimetric, Determination of acetylcholinesterase activity, Biochem. Pharmacol. 7 (1961) 88 (\&).

[16] W.K.W. Leung, R.C.Y. Choi, N.Y.Y. Ip, Z.G. Wu, Y.H. Wong, P.T. Cheung, K.W.K. Tsim, NGF-induced neuronal differentiation of PC12 cells: delineation of signaling molecules and mapping of pathways, Neurosignals 15 (2006), $147-147$.

[17] C.W. Phan, G.S. Lee, S.L. Hong, Y.T. Wong, R. Brkljaca, S. Urban, S.N. Abd Malek, V. Sabaratnam, Hericium erinaceus (Bull.: Fr) Pers. cultivated under tropical conditions: isolation of hericenones and demonstration of NGF-mediated neurite outgrowth in PC12 cells via MEK/ERK and PI3K-Akt signaling pathways, Food Funct. 5 (2014) 3160-3169.

[18] M. Higuchi, K. Onishi, N. Masuyama, Y. Gotoh, The phosphatidylinositol-3 kinase (PI3K)-Akt pathway suppresses neurite branch formation in NGFtreated PC12 cells, Genes Cells 8 (2003) 657-669.

[19] M.W. Wooten, M.L. Seibenhener, G.S. Zhou, M.L. Vandenplas, T.H. Tan, Overexpression of atypical PKC in PC12 cells enhances NGF-responsiveness and survival through an NF-kappa B dependent pathway, Cell Death Differ. 6 (1999) 753-764.

[20] H.Q. Xie, H.M. Xu, H.L. Fu, Q. Hu, W.J. Tian, X.H. Pei, B. Zhao, AhR-mediated effects of dioxin on neuronal acetylcholinesterase expression in vitro, Environ. health Perspect. 121 (2013) 613-618. 